\title{
A SZEMÉLYI JÖVEDELEMADÓ-RENDSZER TÉRBELI VONATKOZÁSAI
}

\section{KOVÁCS CSABA}

A személyi jövedelemadó rendszerét azzal a feltételezéssel dolgozták ki 1987-ben, hogy ez az adófajta teljes egészében a költségvetés bevétele-lesz. Az ennek megfelelốen kimunkált törvénytervezet került az országgyúlési bizottságok elé. Az itt zajló viták során olyan , kompromisszum" született, amely azzal a feltétellel javasolta el fogadásra a tervezet erôsen progresszív és ezért sokat bírált adótábláját, hogy a személyi jỏvedelemadó 1989-tốl kezdve az állampolgárok lakhelye szerint illetékes helyi tanács bevétele legyen. A pénzügyminiszter már ezt a javaslatot terjesztette a parlamenti ülés elé, amit a képviselók jóvá is hagytak.

Az eredeti tervezet kidolgozásakor nem kellett számolni azzal, hogy a helyi tanácsok adóbevétele miként fog alakulni. Kimunkálhattak ezért olyan adótáblázatot is, amely - a 12 ezer forintos adókedvezménnyel együtt - 1 millió állampolgárt mentesített a személyi jövedelemadó tényleges fizetési kötelezettsége alól. A központi költségvetés nézốpontjából közömbös volt, hogy a potenciális adózóknak ez a $20 \%$-a hol lakik. A helyi tanácsokat megilletổ személyi jövedelemadó szempontjából azonban már lényeges volt az a reális lehetốség, hogy a tényleges adófizetési kötelezettség alól mentesítettek aránya egyes településcsoportokban elérheti a 30-40\%-ot, egyes településekben pedig meghaladhatja az 50\%-ot is. Ebbốl következổen már az országgyúlési elócsatározások idószakában is gondolni kellett arra, hogy a helyi tanácsok egy adóalanyra és egy lakosra jutó személyi jövedelemadó bevételeinek nagysága számottevôen különbözni fog egymástól, s hogy a helyi lakosság érdekeltsége is különbözô intenzitású lesz az önkormányzati gazdálkodásban. Úgy tû́nik, hogy az ilyen típusú egyenlốtlenségek várható kialakulása senkit sem izgatott.

A várható egyenlốtlenségek másik típusa abból adódott, hogy az alkalmazottak és a szövetkezeti tagok fổmunkaviszonyból származó bérét kötelezô jelleggel növelték annak érdekében, hogy az fedezetet teremtsen a személyi jövedelemadó kifizetésére. A bérnövelés vállalati és szövetkezeti forrását általában a megszüntetett vagy mérsékelt adók jelentették. A költségvetési intézmények dolgozói esetében közvetlenül a központi költségvetés biztosította a bérek bruttósításához szükséges pénzt. A bérek bruttósítása tehát végsô soron a központi költségvetéssel kapcsolatos és részben a helyi tanácsoknak átengedett pénzeszközök újraelosztását jelentette. Az adótábla progresszivitása következtében a bérek bruttósítására fordított pénzösszeg aránya annál nagyobb volt, minél magasabb volt a fổmunkaviszonyból származó bérek vállalati, szövetkezeti, költségvetési intézményi, egyszóval munkahelyi átlaga.

Akik megegyeztek abban, hogy a személyi jövedelemadó a helyi tanácsok bevétele lesz, azoknak azt is tudniuk kellett, hogy a bérek bruttósítására központilag biztosított pénzeszközökból azok a helyi tanácsok fognak nagyobb arányban részesedni személyi jövedelemadó formájában egy lakosra számítva, amelyek olyan településekben tevékenykednek, ahol átlagosan magasabb keresetũ alkalmazottak és aktív szövetkezeti tagok laknak nagyobb arányban. Azt 
is tudniuk kellett, hogy az ilyen települések tanácsai akkor juthatnak viszonylag több személyi jövedelemadó-bevételhez, ha fokozzák az adózás progresszivitását. Logikailag is nyilvánvaló volt, hogy az ilyen egyenlốtlenségek kialakulása csak akkor akadályozható meg, ha az adózás vagy lineáris, vagy az egyes magánszemélyekre kivetett és a központi költségvetést illetố progresszív adót újraelosztják a helyi tanácsok között a helyben lakó aktív keresók bruttó jövedelme arányában, vagy olyan fejkvóták szerint, amelyek elổnyben részesítik az alacsonyabb jövedelmi színvonalú településeket.

A fentiek lényegi tudásából még nem következett, hogy a kompromisszum megkötổi és megszavazói konkrétan is tudták, hogy a központi költségvetés szempontjai szerint kidolgozott adótábla el fogadható-e a helyi tanácsokat megilletố személyi jövedelemadózás nézôpontjából, vagy az is módosításra szorul. Nyugodtan állíthatom, hogy ezt nem tudták, mert nem végeztették el az ehhez szükséges számításokat. Feltételezhetném, hogy e számítások elvégzéséhez nem állt rendelkezésre sem a szükséges idố, sem a megfelelố statisztikai adatbázis. Ez a feltételezés azonban csak akkor lenne indokolt, ha ezeket a számításokat az adótábla késốbbi módosításai során már elvégezték volna. Erre azonban mind a mai napig nem került sor, noha már 1989 szeptembere, októbere óta konkrét ismereteink vannak arról, hogy a személyi jövedelemadózás 1988. évi rendszere erổteljesen differenciálja a helyi tanácsokat megilletổ személyi jövedelemadó egy lakosra jutó településenkénti nagyságát.

Az illetékesek valami miatt húzódoznak a személyi jövedelemadózás lényeges térbeli összefüggéseinek számbavételétốl. Csak a volt Tervgazdasági Intézet területi osztályán készültek ilyen szándékú számítások és tanulmányok, de nem az adórendszer módosítása, hanem a már adott rendszer területi hatásainak mérlegelése céljából ${ }^{1}$.

\section{Változatok az 1988. évi személyi jövedelemadó rendszerére}

A személyi jövedelemadózás 1987-ben kidolgozott rendszere csak egyike volt a lehetséges változatoknak. Kimunkálói bizonyára gondoltak más lehetôségekre is, de ezeket elvi vagy gyakorlati okok miatt elvetették. Adva volt egy kevésbé progresszív adótábla kialakításának a lehetổsége is. Azzal összefüggésben, hogy a személyi jövedelemadó esetleg tanácsi bevétel lesz, komolyan számításba jöhetett egy lineáris személyi jövedelemadó is. A lineáris adózás puszta lehetốségével már azért is célszerú lett volna számolni, mert a különbözõ progresszivitású adótáblák relatív eltéréseit a megfelelố nagyságú lineáris adóhoz viszonyítva is meg lehetett volna határozni.

Adózási változatok képzésére rendelkezésemre álltak az adóalanyok számára, a bruttó jövedelmük nagyságára és az adótábla szerint számított adójukra vonatkozó 1988. évi településsoros, és településenként az éves bruttó jövedelem öt nagyságcsoportja (sávja) szerint tagolt adatok. Az általam terjedelmileg nem módosítható sávok a következốk voltak: az évi 48 ezer $\mathrm{Ft} /$ fó alatti, a 48 ezer - 120 ezer, a 120 ezer - 240 ezer és a 240 ezer - 360 ezer Ft/fó közötti, valamint a 360 ezer Ft/fô feletti. Az adóalanyok, a bruttó jövedelmek és a személyi jövedelemadó országos összegének ezen sávok szerinti megoszlását, valamint a jövedelem és az adó egy adóalanyra jutó nagyságát az 1. táblázat jelzi. A rendszer igen erôteljes progresszivitását az mutatja, hogy az adóalanyok $70 \%$-a csak 18\%-át adta az adótábla szerint meghatározott adónak, 
ezzel szemben az adóalanyok 4,6\%-ára jutott a levonás nélküli adó összegének 36\%-a. Nagy eltérések voltak a bruttó jövedelembốl és az adóból való részesedés tekintetében is. Ebbôl következôen reális lehetôség volt egy kevésbé progressziv jövedelemadózás bevezetésének is.

1. TÁBLÁZAT

Az 1988. évi személyi jövedelemadó*

\begin{tabular}{ccccccc}
\hline \multirow{2}{*}{$\begin{array}{c}\text { A bruttó } \\
\text { jövedelem } \\
\text { sávjai }\end{array}$} & \multicolumn{2}{c}{ Az adóalanyok } & \multicolumn{2}{c}{ A bruttó jövedelem } & \multicolumn{2}{c}{ Az adó } \\
\cline { 2 - 7 } ezer Ft & $\begin{array}{c}\text { száma } \\
\text { ezer fố }\end{array}$ & $\begin{array}{c}\text { számának } \\
\text { megoszlása } \\
\%\end{array}$ & $\begin{array}{c}\text { egy adó- } \\
\text { alanyra } \\
\text { Ft/fó/év }\end{array}$ & $\begin{array}{c}\text { összegének } \\
\text { megoszlása } \\
\%\end{array}$ & $\begin{array}{c}\text { egy adó- } \\
\text { alany ra } \\
\text { Ft/fô/év }\end{array}$ & $\begin{array}{c}\text { összegének } \\
\text { megoszlása } \\
\%\end{array}$ \\
\hline-48 & 648,1 & 13,5 & 29332 & 3,7 & 0,0 & 0,0 \\
$48-120$ & 2731,4 & 57,0 & 82888 & 44,3 & 4603 & 18,1 \\
$120-240$ & 1193,2 & 24,9 & 158442 & 36,9 & 26526 & 45,7 \\
$240-360$ & 158,5 & 3,3 & 284134 & 8,8 & 80138 & 18,3 \\
360 felett & 62,8 & 1,3 & 517,715 & 6,3 & 197538 & 17,9 \\
Ország & 4794,0 & 100,0 & 106799 & 100,0 & 14460 & 100,0 \\
\hline
\end{tabular}

"Forrás: A Pénzügyi Számítástechnikai Intézet (PSZTI) településsoros adatai

Példaként egy olyan sávos adótáblát dolgoztam ki, amely az elôbbieknek megfelelố sávokban $8,15,23,33$ és 43\%-kal adóztatja a bruttó jövedelmeknek a sáv alsó határa feletti részét, s országosan minden kedvezmény nélkül 69,3 milliárd Ft-os adótömeget biztosít (2. táblázat). Ilyen adókulcsok mellett a két alsó jövedelmi sávba tartozó adózók részesedése az összes fizetendố adóból több, mint a kétszerese az 1988. évi tényleges részesedési aránynak, a két felsố sávba tartozó adózóké pedig csak a 60-64\%-a.

\section{TÁBLÁZAT}

\section{Mérsékelten progresszív adó}

\begin{tabular}{crccccc}
\hline \multirow{2}{*}{$\begin{array}{c}\text { A bruttósított } \\
\text { jövedelem } \\
\text { sávjai }\end{array}$} & \multicolumn{2}{c}{ Az adóalanyok } & \multicolumn{2}{c}{ A bruttó jövedelem } & \multicolumn{2}{c}{ Az adó } \\
\cline { 2 - 7 } ezer Ft & $\begin{array}{c}\text { száma } \\
\text { ezer fón }\end{array}$ & $\begin{array}{c}\text { számának } \\
\text { megoszlása } \\
\%\end{array}$ & $\begin{array}{c}\text { egy adó- } \\
\text { alanyra } \\
\text { Ft/fö/év }\end{array}$ & $\begin{array}{c}\text { összegének } \\
\text { megoszlása } \\
\%\end{array}$ & $\begin{array}{c}\text { egy adó- } \\
\text { alanyra } \\
\text { Ft fó̆/év }\end{array}$ & $\begin{array}{c}\text { összegének } \\
\text { megoszlása } \\
\%\end{array}$ \\
\hline$-52,2$ & 648,1 & 13,5 & 31883 & 4,0 & 2551 & 2,4 \\
$52,2-123,0$ & 2731,4 & 57,0 & 87803 & 46,9 & 9518 & 37,5 \\
$123,0-214,0$ & 1193,2 & 24,9 & 153799 & 35,8 & 21888 & 37,7 \\
$214,0-307,9$ & 158,5 & 3,3 & 252392 & 7,8 & 48395 & 11,1 \\
307,9 felett & 62,8 & 1,3 & 446246 & 5,5 & 126066 & 11,4 \\
Ország & 4794,0 & 100,0 & 106803 & 100,0 & 14469 & 100,0 \\
\hline
\end{tabular}

E változatban az alsó két sávnak megfelelố béreket és fizetéseket az 1988. évinél magasabb arányban kellett volna bruttósítani, a többi sávban pedig alacsonyabb arányban. (Ez a magyarázata a sávhatárok módosulásának.) Lehetséges, hogy ez az összefüggés is befolyásolta a pénzügyi szakembereket abban, hogy a progresszívebb változat mellett döntöttek. Az viszont tény, 
hogy az ipar egyes képviselói a saját iparági vagy vállalati érdekeikbốl kiindulva azt javasolták a parlamentben, hogy a nulla adókulcsos sáv felsố határát emeljék fel 70 ezer Ft-ra, s a 48-120 ezer Ft-os sávon belül ne differenciáják az adókulcsot ${ }^{2}$.

Az adókötelesnek tekintett jövedelmek egy adóalanyra és egy lakosra jutó területi és településcsoportokkénti különbözốsége következtében, a személyi jövedelemadózás bármilyen progresszív kulcsos rendszere szükségképpen azzal a következménnyel jár, hogy az egy adóalanyra, az átlagos jövedelemre és az egy lakosra jutó adó térbeni differenciáltsága fokozódik az adóköteles jövedelmek területi és településcsoportonkénti átlagainak eltéréseihez képest, és e jövedelmek bármekkora százalékában meghatározott lineáris adójához viszonyítva. Ennek mértékeit jelzik a 3.-6. táblázatok.

Ha a progresszív adónak a lineáris adóhoz viszonyitott pozitív elôjelû̉ eltérését adótöbbletnek, a negatív elôjelử eltéréseit pedig elmaradt adónak tekintjük, akkor a jelzett táblázatok fốbb mondanivalóit a következốkben foglalhatjuk össze:

1. A progresszív adórendszer élesen szembeállítja Budapestet a vidék egészével. A vidék elmaradt adója ugyanannyi milliárd forint (7, illetve 3), mint amennyi Budapest adótöbblete.

2. A megyék közül egyedül Komárom megyének van 100 millió Ft körüli adótöbblete. Szabolcs-Szatmár elmaradt adója az 1988. évi tényleges rendszer mellett 1 milliárd Ft, a mérsékelten progresszív változatban 400 millió $\mathrm{Ft}$.

3. TÁBLÁZAT

Személyi jövedelemadó-változatok I.

\begin{tabular}{|c|c|c|c|c|c|c|c|}
\hline & \multirow{5}{*}{$\begin{array}{c}\text { Az adó- } \\
\text { alanyok } \\
\text { száma } \\
\text { ezerben }\end{array}$} & \multicolumn{4}{|c|}{ Egy adóalanyra jutó } & \multirow{2}{*}{\multicolumn{2}{|c|}{$\begin{array}{l}\text { Az adókülönbség összege } \\
\text { a lineáris adóhoz képest }\end{array}$}} \\
\hline & & \multirow{2}{*}{$\begin{array}{l}\text { bruttó } \\
\text { jövedelem }\end{array}$} & \multirow{2}{*}{ adó } & \multirow{2}{*}{$\begin{array}{l}\text { lineáris } \\
\text { adó }\end{array}$} & \multirow{2}{*}{$\begin{array}{c}\text { mérsékelten } \\
\text { progresszív adó }\end{array}$} & & \\
\hline & & & & & & \multirow{2}{*}{$\begin{array}{l}\text { 1988. évi } \\
\text { tényleges }\end{array}$} & \multirow{3}{*}{$\begin{array}{l}\text { mérsékelten } \\
\text { progressziv } \\
6 \mathrm{Ft}\end{array}$} \\
\hline & & \multicolumn{2}{|c|}{ 1988. évi tényleges } & \multirow{2}{*}{\multicolumn{2}{|c|}{$\begin{array}{l}\text { 1988. évi becsült } \\
\text { /fô/êv }\end{array}$}} & & \\
\hline & & & & & & millió Ft & \\
\hline Budapest & 947,1 & 140,4 & 25,7 & 18,0 & 21,1 & 7319 & 2912 \\
\hline Komárom & 153,5 & 112,4 & 16,2 & 15,1 & 15,5 & 169 & 72 \\
\hline Pest & 443.1 & 108,9 & 14,7 & 14,8 & 14,7 & -36 & -35 \\
\hline Fejér & 202,1 & 107,1 & 14,1 & 14,6 & 14,2 & -103 & -68 \\
\hline Veszprém & $187,0^{*}$ & 104,0 & 13,4 & 14,2 & 13,7 & -137 & -87 \\
\hline Baranya & 198,3 & 102,9 & 13,5 & 14,0 & 13,9 & -95 & -14 \\
\hline Gyốr-Sopron & 207,1 & 101,1 & 12,1 & 13,9 & 13,2 & -382 & -158 \\
\hline Csongrád & 195,6 & 99,0 & 11,7 & 13,7 & 13,2 & -385 & -95 \\
\hline Nógrád & 111,8 & 98,1 & 11,5 & 13,6 & 12,7 & -237 & -102 \\
\hline B.-A.-Zemplén & 357,8 & 98,0 & 11,8 & 13,5 & 12,8 & -597 & -256 \\
\hline Tolna & 118,5 & 97,8 & 11,6 & 13,5 & 12,7 & -220 & -95 \\
\hline Heves & 159,6 & 97,0 & 11,0 & 13,5 & 12,4 & -403 & -168 \\
\hline Zala & 142,8 & 95,4 & 10,6 & 13,3 & 12,2 & -387 & -156 \\
\hline Hajdú-Bihar & 246,0 & 94,0 & 10,5 & 13,1 & 12,0 & -636 & -261 \\
\hline Szolnok & 201,2 & 93,7 & 10,2 & 13,1 & 12,0 & -588 & -225 \\
\hline Vas & 134,8 & 93,1 & 9,5 & 13,1 & 11,7 & -483 & -183 \\
\hline Békés & 186,2 & 93,0 & 9,9 & 13,0 & 11,9 & -575 & -212 \\
\hline Somogy & 152,1 & 92,9 & 9,8 & 13,0 & 11,9 & -481 & -174 \\
\hline Bács-Kiskun . & 244,9 & 92,6 & 9,8 & 13,0 & 11,7 & -770 & -308 \\
\hline Szabolcs-Szatmár & 247,6 & 84,3 & 7,8 & 12,0 & 10,4 & -1028 & -396 \\
\hline Ország & $4837,1^{*}$ & 106,8 & 14,5 & 14,5 & 14,4 & -55 & -11 \\
\hline \multicolumn{8}{|l|}{ Ebbốl: } \\
\hline Vidéki városok & 2088,3 & 106,0 & 14,0 & 14,4 & 14,2 & -833 & -445 \\
\hline Községek & 1758,4 & 89,7 & 9,0 & 12,6 & 10,8 & -6453 & -3162 \\
\hline
\end{tabular}

*Becsült érték 
3. A 165 vidéki város közül csak 35 -nek van adótöbblete: az erốsen progresszív változatban 1,6 milliárd Ft, a mérsékelten progresszív változatban 0,6 milliárd Ft. A többi város elmaradt adója 2,5, illetve 1,0 milliárd Ft.

4. A községek elmaradt adója 6,5, ill. 3,2 milliárd Ft. A legalacsonyabb jövedelmi színvonalú községek progresszív adója csak egyharmada az adóköteles jövedelem országos átlagban vett $13,5 \%$-os adóterhének, illetve a feltételezett lineáris adónak.

5. A progresszív adórendszer az aprófalvak, a kis- és közepes lélekszámú községek tanácsait, illetve önkormányzatait magasabb arányban fosztja meg a személyi jövedelemadó bevételének lehetôségétốl, mint a nagyobb lélekszámú településeket.

Ha úgy vezették volna be a személyi jövedelemadó rendszerét, hogy az adót a nettó jövedelembốl kell fizetni, akkor a helyi polgárok zsebébôl annyi pénzt vettek volna ki, amennyi adótöbblete lett volna a megfelelố helyi tanácsnak, illetve önkormányzatnak, az elmaradt adónak megfelelố pénzösszeg pedig a helyi polgárok személyes rendelkezésére állt volna. Egy ilyen rendszer bevezetése jelentôsen mérsékelte volna a személyes rendelkezésú jövedelmek térbeni differenciáltságát, erôsítve a korábbi és az egyéb egyenlősítô tényezốket és tendenciákat.

Más a helyzet akkor, ha az SZJA bevezetésekor az adó összegével növelik a béreket és fizetéseket, és a növekményt az elengedett adókból és más központi forrásokból fedezik. Ebben az esetben a néhány helyi tanács, illetve önkormányzat adótöbblete az adórendszerbốl származó költségvetési ajándék, függetlenül attól, hogy más formában (pl. támogatások megvonása) semmissé teszik ezt az ajándékot. Ugyanilyen szempontból a helyi tanácsok, illetve önkormányzatok elmaradt adója rejtett elvonás, amit csak mennyiségileg ellensúlyozhat az adókiegészítésnek vagy bárminek nevezett központi költségvetési juttatás.

4. TÁBLÁZAT

Személyi jövedelemadó-változatok II.

Vidéki városok

\begin{tabular}{|c|c|c|c|c|c|c|c|c|}
\hline \multirow{4}{*}{$\begin{array}{c}\text { Városok az egy } \\
\text { fốre jutó bruttó } \\
\text { jövedelem nagy- } \\
\text { ságcsoportjai } \\
\text { szerint } \\
\text { e Ft/fö/év }\end{array}$} & \multirow{4}{*}{$\begin{array}{l}\text { A városok } \\
\text { száma } \\
(1990 . \text { I. 1.) }\end{array}$} & \multirow{4}{*}{$\begin{array}{c}\text { Az adó- } \\
\text { alanyok } \\
\text { száma }\end{array}$} & \multicolumn{4}{|c|}{ Egy adóalanyra jutó } & \multirow{2}{*}{\multicolumn{2}{|c|}{$\begin{array}{l}\text { Az adókülönbség összege } \\
\text { a lineáris adóhoz képest }\end{array}$}} \\
\hline & & & \multirow{2}{*}{$\begin{array}{c}\text { bruttó } \\
\text { jövedelem }\end{array}$} & \multirow{2}{*}{ adó } & \multirow{2}{*}{$\begin{array}{c}\text { lineáris } \\
\text { adó }\end{array}$} & \multirow{2}{*}{$\begin{array}{l}\text { mérsékelten } \\
\text { progresszív adó }\end{array}$} & & \\
\hline & & & & & & & \multirow{2}{*}{$\begin{array}{l}\text { 1988. évi } \\
\text { tényleges }\end{array}$} & \multirow{2}{*}{$\begin{array}{l}\text { mérsékelten } \\
\text { progresszív }\end{array}$} \\
\hline & & & $\begin{array}{l}1988 . \\
\text { tényle }\end{array}$ & & fô/év & $\begin{array}{l}\text { 88. évi } \\
\text { ecsüllt }\end{array}$ & & \\
\hline$-89,9$ & 38 & 200,9 & 86,5 & 8,1 & 1 & & & \\
\hline $90,0-99,9$ & 55 & 409,1 & 95,1 & 10,3 & 13,3 & 12,1 & $-1203,8$ & $-491,3$ \\
\hline $100,0-109,9$ & 37 & 674,4 & 105,9 & 13,8 & 14,4 & 14,1 & $-450,7$ & $-220,6$ \\
\hline $110,0-119,9^{*}$ & 25 & 677,2 & 114,5 & 16,8 & 15,3 & 15,8 & 1010,4 & 365,1 \\
\hline $120-* *$ & 10 & 126,7 & 126,7 & 21,3 & 16,5 & 18,3 & 608,8 & 232,0 \\
\hline Együtt & 165 & 2088,3 & 106,0 & 14,0 & 14,4 & 14,2 & $-882,5$ & $-445,3$ \\
\hline
\end{tabular}

"Ebbe a kategóriába tartozó városok az egy adóalanyra jutó jövedelem növekvố sorrendjében: Békéscsaba, Zirc, Siófok, Miskolc, Szeged, Tata, Esztergom, Gárdony, Ráckeve, Vác, Kazincbarcika, Érd, Mór, Nyergesújfalu, Szekszárd, Pécs, Tapolca, Gyổr, Szolnok, Veszprém, Balatonalmádi, Gödölloo, Tatabánya, Székesfehérvár, Dorog.

**Dunaújváros, Dunakeszi, Szentendre, Komló, Szigetszentmikloss, Budaörs, Paks, Oroszlány, Leninváros, Százhalombatta. 
5. TÁBLÁZAT

Személyi jövedelemadó-változatok III.

Szabolcs-Szatmár megye

\begin{tabular}{|c|c|c|c|c|c|c|c|}
\hline \multirow{4}{*}{$\begin{array}{l}\text { Település- } \\
\text { kategóriák }\end{array}$} & \multirow{4}{*}{$\begin{array}{l}\text { A telepü- } \\
\text { lések } \\
\text { száma }\end{array}$} & \multirow{4}{*}{$\begin{array}{c}\text { Az adó- } \\
\text { alanyok } \\
\text { száma }\end{array}$} & \multicolumn{4}{|c|}{ Egy adóalanyra jutó } & \multirow{2}{*}{$\begin{array}{l}\text { Az adókülönbség összege } \\
\text { - a lineáris adóhoz képest }\end{array}$} \\
\hline & & & \multirow{2}{*}{$\begin{array}{c}\text { bruttó } \\
\text { jövedelem } \\
\end{array}$} & \multirow{2}{*}{ adó } & \multirow{2}{*}{$\begin{array}{l}\text { lineáris } \\
\text { adó }\end{array}$} & \multirow{2}{*}{$\begin{array}{l}\text { mérsékelten } \\
\text { progressziv adó }\end{array}$} & \\
\hline & & & & & & & \multirow{2}{*}{$\begin{array}{ll}\text { 1988. évi mérsékelten } \\
\text { tényleges } \\
\text { progressziviv }\end{array}$} \\
\hline & & & 1988. évi & nylege & 1988. & évi becsült & \\
\hline & & fố & \multicolumn{4}{|c|}{ e Ft/fố/év } & millió $\mathrm{Ft}$ \\
\hline
\end{tabular}

Az egy adó-

alanyra jutó

bruttó jöv.

e Ft/fó̉/év

\begin{tabular}{|c|c|c|c|c|c|c|c|c|}
\hline-60 & 13 & 2653 & 55,5 & 2,5 & 8,3 & 6,1 & -15 & -6 \\
\hline $60-70$ & 55 & 20818 & 67,3 & 4,1 & 9,9 & 7,7 & -120 & -46 \\
\hline $70-80$ & 87 & 89265 & 75,7 & 5,4 . & 11,0 & 8,9 & -502 & -191 \\
\hline $80-90$ & 65 & 50103 & 82,4 & 7,0 & 11,8 & 9,9 & -242 & -94 \\
\hline $90-100$ & 4 & 29958 & 92,6 & 9,6 & 13,0 & 11,7 & -102 & -38 \\
\hline $100-110$ & 2 & 54762 & 103,5 & 13,3 & 14,1 & 13,8 & -48 & -20 \\
\hline \multicolumn{9}{|c|}{$\begin{array}{l}\text { Az állandó né- } \\
\text { pesség száma } \\
\text { ezer fố }\end{array}$} \\
\hline$-0,5$ & 27 & 3006 & 65,8 & 3,9 & 9,7 & 7,4 & -17 & -7 \\
\hline $0,5-1$ & 58 & 16609 & 69,9 & 4,7 & 10,2 & 8,1 & -92 & -36 \\
\hline $1-2$ & 63 & 34929 & 74,9 & 5,3 & 10,9 & 8,8 & -195 & -75 \\
\hline $2-3$ & 37 & 35361 & 75,6 & 5,4 & 11,0 & 8,9 & -196 & -75 \\
\hline $3-5$ & 23 & 33693 & 77,5 & 5,8 & 11,2 & 9,2 & -183 & -70 \\
\hline $5-10$ & 12 & 36098 & 82,6 & 7,1 & 11,8 & 10,0 & -171 & -66 \\
\hline $10-15$ & 3 & - $\quad 17748$ & 87,8 & 8,5 & 12,4 & 10,8 & -69 & -28 \\
\hline $15-20$ & 2 & 17722 & 93,2 & 9,6 & 13,1 & 11,9 & -61 & -21 \\
\hline $100-120$ & 1 & 52393 & 103,5 & 13,3 & 14,1 & 13,8 & -43 & -18 \\
\hline Megye & 226 & 247557 & 84,3 & 7,8 & 12,0 & 10,1 & -1028 & -396 \\
\hline
\end{tabular}

A központi állam szempontjából közömbösnek látszik a bevezetett adórendszernek ez a sajátossága, hiszen az adótöbbletet teljesen el is vonhatja, az elmaradt adót pedig teljesen pótolhatja. A helyi tanácsok, illetve az önkormányzatok nézổpontjából azonban nem érdektelen az, hogy a személyi jövedelemadó rendszere tekintetében mekkora a valóságosan és a csak látszólagosan szabad mozgástere. Nem mellékes az sem, hogy mekkora ez a fajta adótöbblet, s hogy mekkora ez a fajta elmaradt adó, adóelvonás vagy adóhiány.

Nem állt módomban megkülönböztetni a kötelezóen bruttósított és a nem bruttósított jövedelmek mennyiségét és adóját, valamint azoknak a településenkénti számát, akiknek a bérét bruttósították, illetve azoknak a számát, jövedelmét és adóját, akik nem vagy nemcsak a fômunkaviszonyból származó jövedelmük után adóztak. Ezért becsülni sem tudtam, hogy Budapest és a 35 város adótöbbletébốl mekkora az átcsoportosított központi pénzeszköz aránya. Akármekkora is azonban ez az arány, a személyi jövedelemadó rendszerének kidolgozásánál nem lett volna szabad eltekinteni újraelosztásának térbeli oldalától. 


\section{Mi lett volna, ha...?}

Tételezzük fel, hogy a személyi jövedelemadó rendszerének kidolgozása során a fentiekhez hasonló számításokat végeznek az illetékes pénzügyi és a terület- és a településfejlesztéssel foglalkozó szervek.

Az elsổ kérdés az, hogy az elvégzett számítások befolyásolták volna-e a személyi jövedelemadó rendszerével kapcsolatos koncepciójukat. A másik kérdés az, hogy ugyanolyan kompromisszumot kötöttek volna-e az országgyứlésben, mint amilyenben a törvényjavaslat plenáris vitája elốtt megállapodtak. Ezzel összefüggésben tételezzük fel azt is, hogy a számítási eredményeket is nyilvánosságra hozták volna.

1987 ôszén minimális valószínứsége sem volt egy olyan személyi jövedelemadó-rendszer elfogadtatásának, amely szemmel láthatóan és egyértelmũen hátrányos helyzetbe hozza a vidéket Budapesttel szemben, az alacsony jövedelmi színvonalú megyéket a viszonylag magas jövedelmú megyékkel szemben, valamint általában a községek és a vidéki városok nagyobb részét a vidéki városok kisebb és kevesebb lelket számláló részével szemben. A vidéki képviselớk határozottan elutasítottak volna egy ilyen személyi jövedelemadó-rendszert, de a budapestiek sem támogatták volna.

Ezzel a teljesen reális lehetốséggel azoknak is számolnia kellett, akik teljes mértékben meg voltak gyõzôdve arról, hogy az adott gazdasági körülmények között legcélszerúbb az a változat, amely erổsen progresszív adókulcsokat alkalmaz és az adót teljes egészében a központi költségvetés bevételévé teszi. Egy ilyen változat elfogadtatásának is megvolt a reális lehetốsége, amenynyiben elổre meghatározottan úgy osztja el a befolyt adót, amely garantáltan mérsékli a fốváros és a vidék, az elmaradottabb és a fejlettebb megyék, valamint a különbözổ településcsoportok közötti gazdasági és ellátottságbeni különbségeket. Ezt a változatot a területi tervezôk és kutatók egy része is támogatta volna. Ezen túlmenôen bizonyítani kellett volna e változat elônyeit a mérsékelten progresszív és a lineáris adóztatással szemben. Csak a gazdasági elốnyök hangsúlyozása azonban nem lett volna elégséges e változat elfogadtatásához.

A személyi jövedelemadó bevezetése az adóreform szerves része volt, de nem volt pusztán a gazdasági reform kérdése. Összefüggésben volt az aktuális politikai reformmal is, a politikai túlcentralizáltság lazításával és a valóságos helyi önkormányzatok kifejlesztésének kérdésével is. Részben ez a szándék húzódott meg annak a kikényszerítése mögött, hogy a személyi jövedelemadó a helyi tanácsok bevétele legyen.

Elegendố egy-egy pillantást vetni a 4. és az 5. táblázatra annak belátásához, hogy egy erôsen progressziv adókulcsos változat nem szolgálhatja a települési önkormányzatok valóságos és viszonylagos gazdasági önállóságának megalapozását, hogy ebbốl a célból a lineảris adóztatás a legmegfelelốbb. Az elvégzett számítások birtokában ezért fel sem merülhetett volna az a gondolat, hogy a helyi önkormányzatok bevételévé tegyék az erősen progresszív adótábla alapján megállapított és fizetendổ személyi jövedelemadốt, s hogy egy ilyen változat valóságos kompromisszum lehetne a centralizáltabb és a decentralizált állam és adóztatás hívei között.

A számítások eredményeiból egyértelmủen az következik, hogy legalább három változatot kellett volna a bevezetendố adórendszerre kidolgozni. Egy lineárisan adóztató rendszert, egy mérsékelten és egy erốteljesen progresszív adótáblát alkalmazó rendszert. Ezek egymáshoz viszonyított elỏnyeit és hátrányait kellett volna alaposan megfontolni. 
A progresszív kulcsos és szúk sávhatárokkal dolgozó személyi jövedelemadó-rendszernek az a fổ elốnye a lineáris személyi jövedelemadóval szemben, hogy az adóbevételek - a sávhatárok gyakoribb átlépése következtében - nagyobb arányban növekednek, mint a névleges jövedelmek. Normális körülmények között az így keletkezett adótöbblet tágítja az adó tulajdonosának mozgásterét, inflációs körülmények között pedig automatikusan fékezi vagy megakadályozza az adó reálértékének csökkenését. Nem biztos azonban, hogy a központi költségvetést illetố progresszív adó tömege nagyobb lesz, mint a települési önkormányzatokat megilletố lineáris adó. Nem pusztán azért, mert a sávosan progresszív adó visszafoghatja a teljesítményeket, hanem azért is, mert a központi szervek számára tágabb a , láthatatlan” jövedelmek köre és nagyobb a volumene, mint a helyi önkormányzatok számára. Az utóbbiak különösebb beavatkozás nélkül is nagyobb arányban képesek ténylegesen megadóztatni az általában láthatatlannak minốsített jövedelmeket, feltéve, hogy az adóbevallásokat hozzájuk nyújtják be. (Egy kisebb településben minden felnốtt tudja, hogy pl. a körzeti orvos elfogad-e hálapénzt vagy sem, s ha elfogad, akkor mekkora ennek a szokás szerinti összege. Kicsi annak a valószínúsége, hogy ez az orvos nagyságrendileg kevesebb hálapénzt vall be, mint amennyit kap.) Hasonló a helyzet azokban a szakmákban, amelyekben köztudott a borravaló szokásos nagysága. 1989-ben 12 ezer orvos átlagosan havi $1257 \mathrm{Ft}$ hálapénzt vallott be, 7610 fodrász pedig havi $416 \mathrm{Ft}$ borravalót (Adó, 1989. júl. 15., 3. old.).

Az erốsen progressziv adóztatás természetes velejárója a kedvezményezettek nagy aránya, amit a lineáris adóztatás teljesen megszüntethet, s amit a helyi önkormányzatokat illetố jövedelemadó esetében természetesen a minimálisra kell csökkenteni. Nem valóságos helyi önkormányzat ugyanis az, amelyben a jogilag az önkormányzathoz tartozó jövedelemtulajdonosok nagy része nem adózik a helyi irányító, vezetố szervének.

Ha 1987-ben kidolgoztak volna egy olyan változatot is, amely lineárisan adóztat és az adó teljes egészében a települési önkormányzatot illeti, akkor ennél a változatnál lényegileg vagy gyakorlatilag kizárhatták volna az adómentességet és a különféle kedvezményeket, s az erősen progresszív változat kimunkálása során sem tervezték volna 1 millió adóalany mentesítését a tényleges adófizetési kötelezettség alól. Legfeljebb addig mentek volna el, hogy az adóalanyok egy része kedvezốbbnek tekintse a központi költségvetést illetố progresszív adó bevezetését, mint a helyi önkormányzatot illetổ lineáris adó fizetését.

Tulajdonképpen csak egyetlen egy racionálisnak látszó gondolat és érv volt a tényleges adómentesség határának meghúzásánál: nem akarták adóztatni az 500 ezer Ft-nál kisebb bevételt biztosító mezôgazdasági kistermelést, mivel féltek ennek visszaesésétôl. Ez a félelem felmerülhetett volna akkor is, ha az adó lineáris és a települési önkormányzatot illeti. Egy ilyen változatnál azonban a félelem nem lett volna elégséges ok a mezôgazdasági kistermelés adómentességének rendszerbe foglalásához. Legfeljebb a saját fogyasztásra történô termelést vonhatták volna ki az adófizetési kötelezettség alól. Senki sem bizonyította, hogy a mezőgazdasági kistermelốk akkor is visszafogják a termelést, ha személyi jövedelemadót fizetnek utána a helyi önkormányzatoknak, bár senki sem lehetett biztos ennek az ellenkezôjében sem. A fố kérdés ebben a vonatkozásban is az volt, hogy a változatok kimunkálói akartak-e egy valóságos helyi önkormányzatot vagy sem, s a valóságos helyi önkormányzatok társadalmi haszna érdekében hajlandók voltak-e némi gazdasági rizikó vállalására.

Az 1988-ban bevezetett rendszer erổteljesen differenciálta a helyi tanácsokat illetố személyi 
jövedelemadót az adóalanyok bruttó jövedelméhez képest (6. táblázat). Ez a tény ellentéteket szülhet a közös tanácsú községek között. A közös önkormányzatból való kiválásra ösztönözhetett olyan településeket, amelyek a jövedelem színvonalukhoz képest több adóbevételre tettek szert. A jelenben ugyanez akadályozhatja az önálló települési önkormányzatok egymással való társulását. Ezek az ellentmondások az alacsony jövedelmi színvonalú települések csoportjaiban jelentenek nagyobb veszélyt.

6. TÁBLÁZAT

A jövedelmek és az adók súlyozotlan átlaga és relatív szórása

\begin{tabular}{|c|c|c|c|c|}
\hline & \multicolumn{2}{|c|}{ Vidéki városok } & \multicolumn{2}{|c|}{$\begin{array}{l}\text { Szabolcs-Szatmár megyei } \\
\text { települések }\end{array}$} \\
\hline & $\begin{array}{l}\text { Átlag } \\
\mathrm{eFt} / \mathrm{fón}\end{array}$ & $\begin{array}{c}\text { Szórás } \\
\%\end{array}$ & $\begin{array}{l}\text { Átlag } \\
\text { eFt/fố }\end{array}$ & $\begin{array}{c}\text { Szórás } \\
\%\end{array}$ \\
\hline \multicolumn{5}{|l|}{ Egy adóalanyra jutó } \\
\hline 1988. évi bruttó jövedelem & 99,8 & 12,4 & 73,5 & 11,1 \\
\hline 1988. évi SZJA & 12,1 & 33,8 & 5,2 & 30,3 \\
\hline lineáris adó & 13,7 & 9,5 & 10,7 & 9,8 \\
\hline mérsékelten progresszív adó & 13,1 & 18,3 & 8,2 & 15,9 \\
\hline
\end{tabular}

Az erổteljesen progresszív adó olyan esetekben is gondot okozhat, amikor az összetartozó önkormányzatok mindegyike jelentốs arányú és tömegư nemzeti ajándékot kap adótöbblet formájában. Mindegyik görcsösen ragaszkodhat a véletlenszerüen kapott teljes adómennyiséghez, noha az adótöbbleten közvetlenül osztozkodhatnának vagy közös célok megvalósítására használhatnák fel azt. Ilyen helyzetet teremtett az 1988. évi rendszer a budapesti kerületek vonatkozásában (7. táblázat).

A fenti érvek is elsősorban a lineáris adóztatás mellett szólnak, de a mérsékelten progresszív adózást is elổnyösebbnek tüntetik fel az erốteljesen progresszív adóval szemben. Messzemenően több gazdasági és társadalmi haszon származhat az önkormányzatok társulásait elómozdító adórendszerból, mint amennyit az ezzel ellentétes irányban ható adórendszer más relációkban hozhat.

Ha a települési önkormányzatok személyi jövedelemadójának arányai lényegében megfelelnek polgáraik lineárisan bruttósított jövedelme és a nettó jövedelme arányainak, akkor az önkormányzatokra lehet bízni az olyan feladatok megoldását, amelyek céljából egy-egy település lakói egyéni érdekeik közös volta következtében ezidáig is társultak, s nincs szükség az adó egyenlốtlenségeit elsimító központi beavatkozásokra.

Ezzel szemben az 1987-ben elfogadott, az 1988. évi jövedelmekre vonatkozó, és a helyi tanácsi költségvetések bevételei között 1990-ben megjelenô személyi jövedelemadót a települések túlnyomó részénél azonnal ki kellett egészíteni egy minimálisnak tartott (állandó lakosokként évi $4000 \mathrm{Ft}$ ) szintre, $\mathrm{s}$ egyedileg kellett kezelni a többi település költségvetési problémáit abban az esetben, ha nyilvánvaló volt, hogy azok a személyi jövedelemadó rendszerével kapcsolatosak. A túlzottan progresszív adóztatás ilyenképpen nem zárta ki sem az újabb központi szabályozás szükségességét, sem kézivezérlés jellegử beavatkozását. Senki sem akart ilyen adórendszet csinálni, bár felkészültek arra, hogy a tényleges személyi jövedelemadó 3-4\%-osnál nagyobb eltérést is okozhat a tanácsi költségvetés bevételi oldalán. 
7. TÁBLÁZAT

Személyi jövedelemadó-változatok IV.

Budapest

\begin{tabular}{|c|c|c|c|c|c|c|c|}
\hline \multirow{4}{*}{ Kerület } & \multirow{4}{*}{$\begin{array}{l}\text { Adóalanyok } \\
\text { száma }\end{array}$} & \multicolumn{4}{|c|}{ Egy adóalanyra jutó } & \multicolumn{2}{|c|}{$\begin{array}{c}\text { Adótöbblet a lineáris } \\
\text { adóhoz képest }\end{array}$} \\
\hline & & $\begin{array}{l}\text { bruttó } \\
\text { jövedelem }\end{array}$ & adó & lineáris adó & $\begin{array}{l}\text { mérsékelten } \\
\text { progresszív adó }\end{array}$ & \multirow{2}{*}{$\begin{array}{l}\text { 1988. évi } \\
\text { tényleges }\end{array}$} & \multirow{2}{*}{$\begin{array}{l}\text { mérsékelter } \\
\text { progresszív }\end{array}$} \\
\hline & & \multicolumn{2}{|c|}{ 1988. évi tényleges } & \multirow{2}{*}{\multicolumn{2}{|c|}{$\begin{array}{l}\text { 1988. évi becsült } \\
\text { Ft/fó/év }\end{array}$}} & & \\
\hline & & & & & & \multicolumn{2}{|c|}{ millió $\mathrm{Ft}$} \\
\hline I. & 17,8 & 164,3 & 35,2 & 20,3 & 26,8 & 266,8 & 116,7 \\
\hline II. & 50,4 & 176,4 & 41,0 & 21,2 & 29,7 & 995,2 & 425,8 \\
\hline HII. & 69,2 & 140,0 & 25,7 & 17,9 & 20,9 & 539,6 & 207,9 \\
\hline IV. & 48,2 & 128,8 & 21,1 & 16,9 & 18,3 & 202,2 & 70,0 \\
\hline v. & 21,9 & 149,3 & 29,0 & 18,9 & 23,0 & 221,8 & 90,9 \\
\hline VI. & 28,0 & 135,0 & 23,6 & 17,4 & 20,0 & 172,1 & 70,1 \\
\hline -VIII. & 35,7 & 130,7 & 22,1 & 17,0 & 19,2 & 182,8 & 79,3 \\
\hline VIII. & 40,6 & 127,4 & 20,8 & 16,7 & 18,3 & 164,8 & 65,4 \\
\hline IX. & 35,5 & 132,4 & 22,4 & 17,2 & 19,3 & 183,4 & 74,7 \\
\hline $\mathrm{X}$. & 44,3 & 129,6 & 21,3 & 17,0 & 18,6 & 193,4 & 71,1 \\
\hline XI. & 82,6 & 156,4 & 31,8 & 19,5 & 24,5 & 1013,7 & 411,1 \\
\hline XII. & 37,2 & 175,9 & 40,6 & 21,2 & 29,6 & 720,9 & 313,2 \\
\hline XIII. & 61,6 & 143,0 & 26,5 & 18,3 & 21,6 & 508,8 & 206,3 \\
\hline XIV. & 66,6 & 142,5 & 26,2 & 18,2 & 21,2 & 527,3 & 200,1 \\
\hline XV. & 47,3 & 128,8 & 21,0 & 16,9 & 18,4 & 196,9 & 70,2 \\
\hline XVI. & 33,9 & 138,6 & 24,7 & 17,9 & 20,4 & 232,5 & 84,9 \\
\hline XVII. & 35,5 & 128,1 & 20,9 & 16,8 & 18,2 & 141,7 & 49,4 \\
\hline XVIII. & 46,0 & 128,0 & 20,9 & 16,9 & 18,4 & 184,7 & 66,1 \\
\hline XIX. & 34,1 & 132,2 & 22,3 & 17,2 & 19,0 & 174,7 & 61,8 \\
\hline XX. & 44,0 & 126,8 & 20,2 & 16,7 & 17,9 & 155,4 & 53,9 \\
\hline XXI. & 42,3 & 130,5 & 21,6 & 17,1 & 18,6 & 192,6 & 64,1 \\
\hline XXII. & 25,2 & 135,3 & 23,4 & 17,5 & 19,8 & 147,9 & 58,0 \\
\hline Együtt & 947,1 & 140,4 & 25,7 & 18,0 & 21,1 & 7319,3 & 2911,6 \\
\hline
\end{tabular}

A nullás adósáv túlzott szélessége arra kényszerítette a személyi jövedelemadó-rendszer kidolgozóit, hogy a ténylegesen megadóztatott jövedelmekre viszonylag magas adót vessenek ki. A felsổ jövedelemsávokban már 50-60\%-os adókulcsot alkalmaztak. Az adóalanyok jövedelmi sávok közötti megoszlásából és a sávosan progresszív adókulcsokból eleve az következett, hogy amint a kormányzat rákényszerül a személyi jövedelemadó tömegének (az automatikus növekedésnél nagyobb arányú) növelésére, akkor kénytelen lesz a nullás sávot szúkíteni vagy megszüntetni, s a felette lévố néhány sávban az adó kulcsát megemelni. Az a lehetốség is adva volt, hogy a kormányzatot rákényszerítik a túlzottan magasnak ítélt adókulcsok leszállítására. Mind a két lehetốség reális volt az adott és a várható körülmények között. Ez a tény azt is jelentette, hogy az adókulcsok változtatásával az alacsonyabb jövedelmư rétegek rovására módosíthatják a nettó jövedelem arányait anélkül, hogy nyîlt bérreformot csinálnának a köztudottan alulfizetett kvalifikált és komoly felelổsséget igénylổ tevékenységeket végzốk javára. A túlzottan progresszív adóztatás egyébként is gátja volt az adóreform és a bérreform együttes kezelésé- 
jövedelemadót az adóalanyok bruttó jövedelméhez képest (6. táblázat). Ez a tény ellentéteket szülhet a közös tanácsú községek között. A közös önkormányzatból való kiválásra ösztönözhetett olyan településeket, amelyek a jövedelem színvonalukhoz képest több adóbevételre tettek szert. A jelenben ugyanez akadályozhatja az önálló települési önkormányzatok egymással való társulását. Ezek az ellentmondások az alacsony jövedelmi színvonalú települések csoportjaiban jelentenek nagyobb veszélyt.

$$
\text { 6. TÁBLÁZAT }
$$

A jövedelmek és az adók súlyozotlan átlaga és relativ szórása

\begin{tabular}{lcccc}
\hline & \multicolumn{2}{c}{ Vidéki városok } & \multicolumn{2}{c}{ Szabolcs-Szatmár megyei } \\
& $\begin{array}{c}\text { Átlag } \\
\mathrm{eFt/fố}\end{array}$ & $\begin{array}{c}\text { Szórás } \\
\%\end{array}$ & $\begin{array}{c}\text { Átlag } \\
\text { eFt/fón }\end{array}$ & $\begin{array}{c}\text { Szórás } \\
\%\end{array}$ \\
\hline Egy adóalanyra jutó & & & & \\
1988. évi bruttó jövedelem & 99,8 & 12,4 & 73,5 & 11,1 \\
1988. évi SZJA & 12,1 & 33,8 & 5,2 & 30,3 \\
líneáris adó & 13,7 & 9,5 & 10,7 & 9,8 \\
mérsékelten progresszív adó & 13,1 & 18,3 & 8,2 & 15,9 \\
\hline
\end{tabular}

Az erổteljesen progresszív adó olyan esetekben is gondot okozhat, amikor az összetartozó önkormányzatok mindegyike jelentôs arányú és tömegũ nemzeti ajándékot kap adótöbblet formájában. Mindegyik görcsösen ragaszkodhat a véletlenszerũen kapott teljes adómennyiséghez, noha az adótöbbleten közvetlenül osztozkodhatnának vagy közös célok megvalósítására használhatnák fel azt. Ilyen helyzetet teremtett az 1988. évi rendszer a budapesti kerületek vonatkozásában (7. táblázat).

A fenti érvek is elsôsorban a lineáris adóztatás mellett szólnak, de a mérsékelten progresszív adózást is elốnyösebbnek tüntetik fel az erôteljesen progresszív adóval szemben. Messzemenóen több gazdasági és társadalmi haszon származhat az önkormányzatok társulásait elổmozdító adórendszerból, mint amennyit az ezzel ellentétes irányban ható adórendszer más relációkban hozhát.

Ha a települési önkormányzatok személyi jövedelemadójának arányai lényegében megfelelnek polgáraik lineárisan bruttósított jövedelme és a nettó jövedelme arányainak, akkor az önkormányzatokra lehet bízni az olyan feladatok megoldását, amelyek céljából egy-egy település lakói egyéni érdekeik közös volta következtében ezidáig is társultak, s nincs szükség az adó egyenlốtlenségeit elsimító központi beavatkozásokra.

Ezzel szemben az 1987-ben elfogadott, az 1988. évi jövedelmekre vonatkozó, és a helyi tanácsi költségvetések bevételei között 1990-ben megjelenố személyi jövedelemadót a települések túlnyomó részénél azonnal ki kellett egészíteni egy minimálisnak tartott (állandó lakosokként évi $4000 \mathrm{Ft}$ ) szintre, s egyedileg kellett kezelni a többi település költségvetési problémáit abban az esetben, ha nyilvánvaló volt, hogy azok a személyi jövedelemadó rendszerével kapcsolatosak. A túlzottan progresszív adóztatás ilyenképpen nem zárta ki sem az újabb központi szabályozás szükségességét, sem kézivezérlés jellegủ beavatkozását. Senki sem akart ilyen adórendszet csinálni, bár felkészülttek arra, hogy a tényleges személyi jövedelemadó 3-4\%-osnál nagyobb eltérést is okozhat a tanácsi költségvetés bevételi oldalán. 
7. TÁBLÁZAT

Személyi jövedelemadó-változatok IV.

Budapest

\begin{tabular}{|c|c|c|c|c|c|c|c|}
\hline \multirow{4}{*}{ Kerület } & \multirow{4}{*}{$\begin{array}{l}\text { Adóalanyok } \\
\text { száma }\end{array}$} & \multicolumn{4}{|c|}{ Egy adóalanyra jutó } & \multicolumn{2}{|c|}{$\begin{array}{c}\text { Adótöbblet a lineáris } \\
\text { adóhoz képest }\end{array}$} \\
\hline & & $\begin{array}{l}\text { bruttó } \\
\text { jövedelem }\end{array}$ & adó & lineáris adó & $\begin{array}{l}\text { mérsékelten } \\
\text { progresszív adó }\end{array}$ & \multirow{2}{*}{$\begin{array}{l}\text { 1988. évi } \\
\text { tényleges }\end{array}$} & \multirow{2}{*}{$\begin{array}{l}\text { mérsékelter } \\
\text { progresszí }\end{array}$} \\
\hline & & \multicolumn{2}{|c|}{ 1988. évi tényleges } & \multirow{2}{*}{\multicolumn{2}{|c|}{$\begin{array}{l}\text { 1988. évi becsült } \\
\text { fô/év }\end{array}$}} & & \\
\hline & & & & & & \multicolumn{2}{|c|}{ millió $\mathrm{Ft}$} \\
\hline I. & 17,8 & 164,3 & 35,2 & 20,3 & 26,8 & 266,8 & 116,7 \\
\hline II. & 50,4 & 176,4 & 41,0 & 21,2 & 29,7 & 995,2 & 425,8 \\
\hline III. & 69,2 & 140,0 & 25,7 & 17,9 & 20,9 & 539,6 & 207,9 \\
\hline IV. & 48,2 & 128,8 & 21,1 & 16,9 & 18,3 & 202,2 & 70,0 \\
\hline V. & 21,9 & 149,3 & 29,0 & 18,9 & 23,0 & 221,8 & 90,9 \\
\hline VI. & 28,0 & 135,0 & 23,6 & 17,4 & 20,0 & 172,1 & 70,1 \\
\hline VII. & 35,7 & 130,7 & 22,1 & 17,0 & 19,2 & 182,8 & 79,3 \\
\hline VIII. & 40,6 & 127,4 & 20,8 & 16,7 & 18,3 & 164,8 & 65,4 \\
\hline IX. & 35,5 & 132,4 & 22,4 & 17,2 & 19,3 & 183,4 & 74,7 \\
\hline$X$ & 44,3 & 129,6 & 21,3 & 17,0 & 18,6 & 193,4 & 71,1 \\
\hline XI. & 82,6 & 156,4 & 31,8 & 19,5 & 24,5 & 1013,7 & 411,1 \\
\hline XII. & 37,2 & 175,9 & 40,6 & 21,2 & 29,6 & 720,9 & 313,2 \\
\hline XIII. & 61,6 & 143,0 & 26,5 & 18,3 & 21,6 & 508,8 & 206,3 \\
\hline XIV. & 66,6 & 142,5 & 26,2 & 18,2 & 21,2 & 527,3 & 200,1 \\
\hline XV. & 47,3 & 128,8 & 21,0 & 16,9 & 18,4 & 196,9 & 70,2 \\
\hline XVI. & 33,9 & 138,6 & 24,7 & 17,9 & 20,4 & 232,5 & 84,9 \\
\hline XVII. & 35,5 & 128,1 & 20,9 & 16,8 & 18,2 & 141,7 & 49,4 \\
\hline XVIII. & 46,0 & 128,0 & 20,9 & 16,9 & 18,4 & 184,7 & 66,1 \\
\hline XIX. & 34,1 & 132,2 & 22,3 & 17,2 & 19,0 & 174,7 & 61,8 \\
\hline $\mathrm{XX}$. & 44,0 & 126,8 & 20,2 & 16,7 & 17,9 & 155,4 & 53,9 \\
\hline XXI. & 42,3 & 130,5 & 21,6 & 17,1 & 18,6 & 192,6 & 64,1 \\
\hline XXII. & 25,2 & 135,3 & 23,4 & 17,5 & 19,8 & 147,9 & 58,0 \\
\hline Együtt & 947,1 & 140,4 & 25,7 & 18,0 & 21,1 & 7319,3 & 2911,6 \\
\hline
\end{tabular}

A nullás adósáv túlzott szélessége arra kényszerítette a személyi jövedelemadó-rendszer kidolgozóit, hogy a ténylegesen megadóztatott jövedelmekre viszonylag magas adót vessenek ki. A felsố jövedelemsávokban már 50-60\%-os adókulcsot alkalmaztak. Az adóalanyok jövedelmi sávok közötti megoszlásából és a sávosan progresszív adókulcsokból eleve az következett, hogy amint a kormányzat rákényszerül a személyi jövedelemadó tömegének (az automatikus növekedésnél nagyobb arányú) növelésére, akkor kénytelen lesz a nullás sávot szúkíteni vagy megszüntetni, s a felette lévổ néhány sávban az adó kulcsát megemelni. Az a lehetốség is adva volt, hogy a kormányzatot rákényszerítik a túlzottan magasnak ítélt adókulcsok leszállítására. Mind a két lehetôség reális volt az adott és a várható körülmények között. Ez a tény azt is jelentette, hogy az adókulcsok változtatásával az alacsonyabb jövedelmú rétegek rovására módosíthatják a nettó jövedelem arányait anélkül, hogy nyílt bérreformot csinálnának a köztudottan alulfizetett kvalifikált és komoly felelốsséget igénylő tevékenységeket végzốk javára. A túlzottan progresszív adóztatás egyébként is gátja volt az adóreform és a bérreform együttes kezelésé- 
nek. Bonyolultabbá tette volna a feladat megoldását és olyan arányban növelte volna egyes rétegek bruttó jövedelmét, amely más rétegek tagjainak jelentôs részében ellenérzéseket váltott volna ki annak ellenére, hogy a nettó jövedelmi arányok megváltoztatását indokoltnak ismerték volna el.

Ha 1987-ben kidolgoznak egy lineáris adóváltozatot is, akkor ezzel egy olyan alternatívát is megfontolnak és felmutatnak, amely maga semmilyen bonyodalmat nem okozhat a bérreformmal való összekapcsolásában, és a jövốben szabad kezet ad az adókulcs módosításához, differenciálásához.

A progresszív változatok több milliárd Ft-os budapesti és néhány vidéki városra korlátozódó adótöbblete felhívta volna a figyelmet arra, hogy térbeli szempontból is indokolt a bérek, az árak és az adók egyidejử rendezése.

A helyi önkormányzatokat megilletô lineáris személyi jövedelemadót csak egy , hajszálnyi” választja el a helyi önkormányzat által meghatározott és beszedett lineáris személyi jövedelemadótól: egy olyan törvény, amely megszabja a lineáris adó országos középértékét (pl. a bruttó jövedelem 15\%-a), az ettól megengedett eltérés törvényes mértékét (pl. $\pm 1,5$ százalékpont), $\mathrm{s}$ felhatalmazza a helyi önkormányzatokat arra, hogy inflációs körülmények között emelhessék az adókulcsot az adó reálértékének megôrzése érdekében. Ezzel összefüggésben a személyi jövedelemadó és a helyi adók kérdése is együttes átgondolást igényelt. Azt is megfontolás tárgyává lehetett és kellett volna tenni, hogy melyik adóváltozat bevezetése és üzemeltetése kerül kevesebb pénzbe, $s$ melyik változat alkalmazásából tanulhatnak a legtöbbet az adózó és adóztató polgárok.

Ez utóbbiakból következôen 4 változatot is kidolgozhattak volna az 1988. évi jövedelmek utáni személyi jövedelemadóra. Ebból kettổ sávonként növekvố adókulcsokat alkalmazott volna, kettổ pedig lineárisan adóztatott volna. A két progresszív kulcsú változat közül az egyik a ténylegesen kidolgozotthoz állt volna közelebb, a másik progresszivitása mérsékeltebb lett volna. A két lineáris változat közül az egyik teljesen a helyi önkormányzatok jogkörébe utalta volna az adókulcs konkrét nagyságának meghatározását, az adó kivetését és beszedését stb.

Ha a négy változat az országgyưlési képviselớk elé kerül az itteniekhez hasonló számítási eredményekkel együtt, akkor valószínúleg sem a képviselôk, sem a pénzügyi kormányzat emberei, sem a kormány tagjai nem mentek volna bele abba, amiben 1987-ben megegyeztek és amire törvényt hoztak.

\section{Prolongált ellentmondások az 1989. évi SZJA elosztásában}

A ,,Mi lett volna, ha...?" kérdése nem korlátozható az SZJA 1988. évi bevezetése előtti idôszakra. Még az 1991. évi személyi jövedelemadóra vonatkozó változatokat is olyan körülmények között készítették, hogy nem ismerték a személyi jövedelmek konkrét térbeni megoszlását, noha már a megfelelổ 1988. és 1989. évi adatokat is felhasználhatták volna, ha a Pénzügyi Számítástechnikai Intézettól megkérik azokat. Ebbốl következôen felvethetổ az a kérdés is, hogy az új pénzügyi kormányzat milyen javaslatot dolgozott volna ki a személyi jövedelemadó rendszerének módosítására és az új kormány milyen javaslatot terjesztett volna az országgyuúlés elé abban az esetben, ha a fenti vagy hasonló számítási eredmények birtokában van, s milyen módo- 
sításokat javasoltak, illetve fogadtak volna el az új országgyưlés pártjai és tagjai ilyen vagy részletesebb ismeretek birtokában.

1990. végén az országgyưlésnek a következô kérdéskörökben lehetett és kellett döntenie a személyi jövedelemadó rendszerével kapcsolatban:

a) Hogyan osszák el a helyi önkormányzatok között az 1989. évi személyi jövedelmek után ténylegesen befizetett és a helyi önkormányzatokat az 1991. évi költségvetési évben törvényesen megilletô adót?

b) Hogyan szabályozzák az 1991. évi személyi jövedelmek utáni adózást?

Az elsố kérdéskörben a következổ választási lehetôségek voltak:

- Továbbra is megkapják-e a települési önkormányzatok az állandó lakóik által két évvel korábban befizetett személyi jövedelemadó $100 \%$-át vagy sem?

- Változtassanak-e a települési önkormányzatokat megilletổ adó vagy adórész önkormányzatok közötti elosztási arányain vagy sem?

A törvényjavaslat mind a két kérdésben nemleges álláspontra helyezkedett. A költségvetési törvény határozata a következỗ: ,,A települési önkormányzatot az állandó lakosság által 1989-re bevallott - az Adóés Pénzügyi Ellenőrzési Hivatal által településenként kimutatott - személyi jövedelemadó 50\%-a illeti meg. Azoknak az önkormányzatoknak, amelyeknél az 1989. január 1-jei állapot szerinti, egy állandó lakosra jutó személyi jövedelemadó bevétel nem éri el a 3200 Ft-ot, a bevételt e szintig kiegészítik. Ezen túlmenóen azon városi önkormányzatoknak, amelyeknél az így számított összeg nem éri el az $5000 \mathrm{Ft}$-ot, a bevételt e szintig, de legfeljebb 25 millió forinttal, az állami költségvetés kiegészíti." ${ }^{3}$

A törvényjavaslatot a következốkkel indokolták: ,, Az 1990. évi tapasztalatok alapján a személyi jövedelemadó szabályozása, miszerint a két évvel korábbi SZJA 100\%-ban a lakóhely szerint illetékes tanács bevétele - nem felel meg az elvárásoknak, nem teremti meg a kapcsolatot a helyi jövedelmi háttér és a helyhatóság gazdasági ereje között. Ellenkezôleg, a foglalkoztatásban és a jövedelmekben meglévổ különbségeket az adó felerổsíti, esetenként eltorzítja a benne lévố - elsốsorban a mezốgazdasági kistermelést ösztönzổ - kedvezmények révén. A nagyfokú differenciálódás, $\mathrm{s}$ az emiatt szükséges kiegészítổ mehanizmus együttesen azt indokolják, hogy az önkormányzati bevételekben mérséklốdjék ennek az adóbevételnek a jelentôsége... Az 50\%-os mértékư átengedés, és a másik 50\% állami támogatássá való átalakítása mellett szól az, hogy az új normatív támogatási elemek forrásfedezetére csak így nyílik lehetốség." (U.o. 71. old.)

Ha az 1988. és 1989. évi személyi jövedelemadó elosztásának területi vonatkozásait összevetjük, az alábbi összefüggésekre mutathatunk rá.

1988-ban az egy lakosra jutó adóköteles jövedelem megyei szintŭ súlyozott relatív szózása $20 \%$-os volt, ezzel szemben az egy lakosra jutó személyi jövedelemadó relatív szórása elérte a 46\%-ot. 1989-re az egy lakosra jutó jövedelmek megyei szintű́ relatív szórása 22\%-ra emelkedett. Ezzel ellentétben az egy lakosra jutó személyi jövedelemadó relatív szórása $44 \%$-ra esett vissza az adótábla progresszivitásának mérséklése és a nullás kulccsal adózók arányának csöok-

kenése következtében. Ám az adó szórásának ez a mértéke még mindig túlzottan magas szintũ volt, ami indokolttá tette a további mérséklésre irányuló törekvéseket.

Az 1991-re megváltozott ,,átengedési arány", vagyis a helyben maradó személyi jövedelemadó $50 \%$-ra való csökkentése azonban semmit sem változtat eme adónem relatív szórásán, tehát 
nem mérsékli a túlzott progresszivitás okozta egyenlốtlenségeket. Ezt a törekvést csak az a 6980 millió forint szolgálja, amelybốl községeknél 3200 Ft-ra, városoknál 5000 Ft-ra egészítik ki (ha a kiegészítés teljes összege nem haladja meg a 25 millió Ft-ot) azoknak az önkormányzatoknak az egy állandó lakosra jut SZJA bevételét, amelyeknél a polgáraik által befizetett 1989. évi személyi jövedelemadó 50\%-ának egy lakosra jutó nagysága nem éri el a megfelelố határt.

A jelenleg alkalmazott elvek szerint mind a községi, mind a városi jogállású települések túlnyomó többsége adókigészítésben részesül. 1991-ben a 2900 községből 2670 község kapállandó lakosonként $3200 \mathrm{Ft}$-ot, amely összegbốl átlagosan 2000 Ft-ot (62,5\%-ot) tesz ki az állandó lakók által befizetett adó és $1200 \mathrm{Ft}$-ot (37,5\% -ot) az adókiegészítés. Ugyanakkor az adópótlékban részesüló 139 város esetében átlagosan $81 \%$ az állandó népességük által kifizetett SZJA és $19 \%$ a kiegészítés.

Az adókiegészítésnek ez a módszere ellentmond a személyi jövedelemadózás természetének, vagyis annak, hogy az elosztás a jövedelmek meghatározott formái (pl. az összes adóköteles jövedelem, az adóalap vagy az adózott jövedelem) szerint történjék, nem elfedve, hanem vállalva és megổrizve az e szférákban létrejött különbségeket. (Ami nem jelenti azt, hogy más források nem szolgálhatnának a kompenzáció alapjául.) Az erôsen progresszív személyi jövedelemadó települési önkormányzatok szerinti differenciálódását ugyanis csak azzal a módszerrel lehet lényegesen mérsékelni a személyi jövedelemadó természetének megfelelôen, amely a befizetett adót teljes egészében a központi költségvetés bevételeként kezeli és a teljes bevétel meghatározott százalékát az állandó lakosságuk adóalapja alapján osztja el az önkormányzatok között. Ezzel a módszerrel a felére lehetett volna csökkenteni az önkormányzatokat megilletố személyi jövedelemadó egy lakosra jutó nagyságának relatív szórását akkor is, ha a teljes országos bevétel $100 \%$-át vagy $50 \%$-át osztják el közöttük. Ez a módszer egyesíti a progresszív és a lineáris adóztatás elônyeit, $\mathrm{s}$ felfogható az önkormányzatok bevételéhez való normatív állami hozzájárulásként is. E formula szerint az 1989. évi országos adóalap szerinti norma $100 \mathrm{Ft}$ adóalap után $16,1 \mathrm{Ft}$, ha az országos SZJA-bevétel $100 \%$-a illeti meg az önkormányzatokat.

Nyilvánvaló, hogy mind az adókiegészítésben részesülő települések körének, mind az adókiegészítés részarányának mértéke az adótábla túlzott progresszivitását igazolja egyrészt, abból következik és azt kompenzálja másrészt. Ugyanakkor az is egyértelmü, hogy mind a községek, mind a városok esetében túlzottan magasan van megállapítva az a határ, ahonnan az egy állandó lakosra jutó adóhoz kiegészítés jár. A jelenlegi arányok a parlamenti képviselốknek a pénzügyi kormányzat által beterjesztett indítványt módosító döntésének következményeképpen alakultak ki. Az eredeti javaslat értelmében ugyanis csupán $2500 \mathrm{Ft} /$ lakos volt az a határ a községek vonatkozásában, amelyre az ennél alacsonyabb értékeket kiegészíteni szándékoztak. (A városok számára tett javaslatot a képviselốk jóváhagyták.) E parlamenti döntés következtében azonban a nivelláló, rendszeridegen elem erôsödött a személyi jövedelemadózás rendszerében, ami ezáltal még ellentmondásosabbá vált, mint korábban volt.

A pénzügyi kormányzat eredeti álláspontja az volt, hogy a személyi jövedelemadó továbbra is teljes, $100 \%$-os átengedésével erôsödhet az önkormányzatok önfinanszírozó képessége. Az eredeti elképzeléseket a normatív állami hozzájárulás körének bốvítése, az intézményhálózat zavartalanabb mû́ködtetése és a pénzeszközök felhasználási hely szerinti allokációjának javítása céljából adták fel. E változtatások mellett szólt látszólag az is, hogy a nagyarányú infláció követ- 
8. TÁBLÁZAT

Népesség, jövedelem- és adóeloszlás megyénként

\begin{tabular}{|c|c|c|c|c|c|c|c|}
\hline \multirow[b]{3}{*}{ Budapest } & \multirow{2}{*}{$\begin{array}{c}\text { Állandó } \\
\text { népesség } \\
\text { 1990. I. } 1 .\end{array}$} & \multirow[t]{2}{*}{$\begin{array}{l}\text { Adóköteles } \\
\text { jövedelem }\end{array}$} & \multirow{2}{*}{$\begin{array}{l}\text { Adóalap } \\
1989 \\
\text { rszág }=100\end{array}$} & \multirow{2}{*}{$\begin{array}{l}\text { Adózott } \\
\text { (nettó) } \\
\text { jövedelem }\end{array}$} & \multirow[t]{2}{*}{ SZJA } & \multirow{2}{*}{\multicolumn{2}{|c|}{$\begin{array}{c}\text { Az adoalap jövedelem } \\
\text { arányában elosztott adó } \\
\text { a progresszív adó } \\
\text { százalékában }\end{array}$}} \\
\hline & & & & & & & \\
\hline & 18,6 & 26,4 & 27,2 & 24,9 & 35,5 & 77 & 70 \\
\hline Baranya & 4,0 & 3,7 & 3,7 & 3,8 & 3,3 & 111 & 113 \\
\hline Bács-Kiskun & 5,3 & 4,3 & 4,3 & 4,5 & 3,5 & 122 & 129 \\
\hline Békés & 4,0 & 3,4 & 3,3 & 3,5 & 2,8 & 120 & 126 \\
\hline Borsod-Abaúj-Z. & 7,6 & 6,7 & 6,6 & 6,8 & 5,8 & 113 & 117 \\
\hline Csongrád & 4,2 & 3,9 & 3,9 & 4,0 & 3,5 & 112 & 114 \\
\hline Fejér & 4,0 & 4,2 & 4,2 & 4,2 & 4,1 & 102 & 103 \\
\hline Gyốr-Moson-Sopron & 4,1 & 4,1 & 4,1 & 4,2 & 3,7 & 111 & 114 \\
\hline Hajdú-Bihar & 5,3 & 4,5 & 4,4 & 4,6 & 3,9 & 114 & 119 \\
\hline Heves & 3,3 & 2,9 & 2,9 & 3,0 & 2,4 & 121 & 126 \\
\hline Komárom-Esztergom & 3,0 & 3,3 & 3,2 & 3,3 & 3,2 & 101 & 101 \\
\hline Nógrád & 2,2 & 2,0 & 2,0 & 2,1 & 1,7 & 119 & 123 \\
\hline Pest & 9,1 & 9,3 & 9,3 & 9,3 & 9,2 & 101 & 101 \\
\hline Somogy & 3,3 & 2,7 & 2,7 & 2,8 & 2,2 & 123 & 128 \\
\hline Szabolcs-Szatmár-Bereg & 5,7 & 3,8 & 3,7 & 4,0 & 2,8 & 133 & 144 \\
\hline Jász-Nagykun-Szolnok & 4,2 & 3,7 & 3,6 & 3,8 & 3,1 & 119 & 124 \\
\hline Tolna & 2,5 & 2,2 & 2,1 & 2,2 & 1,8 & 118 & 123 \\
\hline Vas & 2,6 & 2,5 & 2,4 & 2,5 & 1,9 & 126 & 134 \\
\hline Veszprém & 3,7 & 3,8 & 3,7 & 3,8 & 3,5 & 108 & 111 \\
\hline Zala & 3,0 & 2,7 & 2,6 & 2,8 & 2,2 & 119 & 121 \\
\hline $\begin{array}{l}\text { Ország (ezer fô, } \\
\text { millió } \mathrm{Ft}^{*} \text { ill. \%) }\end{array}$ & 10547 & 620485 & 558793 & 530499 & 89986 & 100 & 100 \\
\hline
\end{tabular}

*Forrás: Pénzügyi Számítástechnikai Intézet

9. TÁBLÁZAT

Jövedelmek és adóeloszlás településtipusonként, 1989

\begin{tabular}{|c|c|c|c|c|c|c|}
\hline & \multirow[t]{2}{*}{$\begin{array}{l}\text { Adóköteles } \\
\text { jövedelem }\end{array}$} & \multirow[t]{2}{*}{ Adóalap } & \multirow{2}{*}{$\begin{array}{c}\begin{array}{c}\text { Adózott } \\
\text { (nettó) } \\
\text { jövedelem }\end{array} \\
=100\end{array}$} & \multirow[t]{2}{*}{ SZJA } & Az adóalap & $\begin{array}{l}\text { Az adózott } \\
\text { jövedelem }\end{array}$ \\
\hline & & & & & \multicolumn{2}{|c|}{$\begin{array}{c}\text { szerint elosztott adó } \\
\text { a progresszív adó } \\
\text { százalékában }\end{array}$} \\
\hline Budapest & 26,4 & 27,2 & 24,9 & 35,5 & 77 & 70 \\
\hline Megyeszékhelyek & 19,8 & 19,9 & 19,6 & 20,7 & 96 & 95 \\
\hline Többi város & 23,6 & 23,5 & 24,1 & 21,7 & 108 & 111 \\
\hline \multicolumn{7}{|l|}{ Önálló tanácsú nagyközség } \\
\hline vagy község & 14,2 & 13,9 & 14,7 & 11,0 & 126 & 134 \\
\hline Közös tanácsok székhelyközsége & 10,0 & 9,7 & 10,4 & 7,2 & 134 & 144 \\
\hline Társközségek & 6,0 & 5,8 & 6,3 & 3,8 & 151 & 166 \\
\hline
\end{tabular}


keztében az 1989. évi SZJA 100\%-os átengedése sem biztosíthatta volna az önfinanszírozás korábbi körét és mértékét.

Nem szükségszerủ és nem elkerülhetetlen azonban a helyi önkormányzatokat megilletô személyi jövedelemadó elosztásának jelenleg érvényben lévố szabályozása, amely szerint az önkormányzatok folyó költségvetési évi SZJA bevétele a két évvel korábbi jövedelmek után befizetett adó névleges értéke szerint alakul. Ennek következtében ugyanis az önkormányzatok reálértékben kevesebb adóbevételre tesznek szert, mint amekkora a polgáraik által befizetett adó két évvel korábbi reálértéke volt - 1989 és 1991 vonatkozásában legalábbis ez a helyzet. Technikailag nincs akadálya annak, hogy az önkormányzatok a folyó évi országos SZJA-ból részesedjenek a befizetett adóból vagy az adóalapból való részesedésük korábbi aránya szerint. (Pl. az elsô félévben a két évvel korábbi, a második félévben az egy évvel korábbi arányok alapján.)

Az 1991. évi előirányzat szerint a ténylegesen fizetendố progresszív személyi jövedelemadó közel 190\%-a lesz az 1989. évi ténylegesen fizetett adónak. Ha a többlet felét az önkormányzatok kapták volna meg, akkor $45 \%$-kal, országosan 40 milliárd forinttal lehetett volna növelni a helyi önkormányzatokat megilletố 1989. évi személyi jövedelemadó tömegét. Így 130 milliárd forint lett volna a nekik átengedett SZJA összege, ami 2,9 szerese az 1989. évi összeg 50\%-ának. Ezért egyáltalán nem meggyổzố az az indoklás, hogy az önkormányzatok által finanszírozott intézmények zavartalan múködésének érdekében kellett csökkenteni az önkormányzatokat megilletổ személyi jövedelemadó arányát és tömegét, a költségvetésükhöz való normatív állami támogatás körének és mennyiségének egyidejứ kiszélesítése és növelése mellett.

A 10. és 11. táblázatok adataiból kiolvasható, hogy milyen alternatívák között lehetett volna választani a helyi önkormányzatok személyi jövedelemadó bevételei tekintetében, ha a döntéselókészítés folyamata alternatív javaslatok kidolgozását jelentette volna. Az 1989. évi tényleges SZJA 100 és 50\%-os értékeinek az adóalap arányában elosztott adó 100 és $50 \%$-os értékeivel való egybevetése ugyanazokat a szabályszerú eltéréseket jelzi, mint amelyeket az 1988. évi személyi jövedelemadó tényleges és lineáris változatainak összehasonlításánál már megállapíthattunk. Budapest adótöbblete 1989-ben is 7,5 milliárd forint volt az adóalap arányában kapott lineáris adóhoz képest, a Szabolcs-Szatmár-Bereg megyei önkormányzatok elmaradt adója 1 milliárd forint közelében maradt. Általában kis adótöbblete volt a megyeszékehelyeknek, a többi településcsoport elmaradt adója pedig annál nagyobb arányú volt, minél alacsonyabb szinten helyezkedtek el a közigazgatási hierarchiában.

Ugyenezen táblázatok igazolják azt az összefüggést is, hogy a központosított, majd az adóalap arányában 100 vagy $50 \%$ erejéig redisztribúció alá esô adó az adóalap arányában osztja el azokat a központi pénzeket, amelyeket 1988-ban a fổmunkaviszonyból származó bérek bruttósítására fordítottak. Ettốl függetlenül is: az adóköteles jövedelem alacsonyabb szintjén elhelyezkedő települések ,,adóbevétele” így átlagosan olyan arányban haladná meg az 1989. évi tényleges adóbevételüket, hogy az gyakorlatilag is feleslegessé tenné olyan, a jövedelemadóztatás természetétốl idegen eszközök alkalmazását, mint amilyen az adókiegészítés a jelenlegi rendszerben.

Csak a budapesti önkormányzatok és a lényegében a 4. táblázatnál felsorolt viszonylag magas jövedelmi színvonalú városi önkormányzatok érdekei voltak ellentétesek a személyi jövedelemadó centralizálásával és az adóalap arányában történổ újraelosztásával. A pénzügyi, valamint a terület- és településfejlesztési kormányzat êrdekei az adóalappal arányos újraelosztás mellett 
10. TÁBLÁZAT

Változatok az 1989. évi SZJA-ra. I.

\begin{tabular}{|c|c|c|c|c|c|c|c|}
\hline & \multicolumn{2}{|c|}{$\begin{array}{c}\text { Az 1989. évi tényle- } \\
\text { gesen fizetett } \\
\text { adó* }^{*}\end{array}$} & \multicolumn{2}{|c|}{$\begin{array}{c}\text { Az 1989. évi adóalap } \\
\text { 16,1 \%-ának megfelelố } \\
\text { adó }\end{array}$} & \multirow[t]{2}{*}{$\begin{array}{l}\text { Az } 1989 . \\
\text { évi tényle- } \\
\text { ges adó } \\
145 \% \text {-a }\end{array}$} & \multirow[t]{2}{*}{$\begin{array}{c}\text { Az } 1989 \text {. évi } \\
\text { adóalap ará- } \\
\text { nyában le- } \\
\text { bontott adó } \\
145 \% \text {-a }\end{array}$} & \multirow[t]{2}{*}{$\mathrm{Max} / \mathrm{min}$} \\
\hline & $100 \%$ & $50 \%$ & $\begin{array}{l}\text { millió forint } \\
100 \%\end{array}$ & $50 \%$ & & & \\
\hline Baranya & 2986 & 1493 & 3302 & 1651 & 4330 & 4788 & 3,2 \\
\hline Bács-Kiskun & 3141 & 1571 & 3841 & 1922 & 4554 & 5569 & 3,5 \\
\hline Békés & 2494 & 1247 & 2993 & 1497 & 3616 & 4340 & 3,5 \\
\hline Borsod-Abaúj-Zemplén & 5252 & 2626 & 5919 & 2960 & 7615 & 8583 & 3,3 \\
\hline Csongrád & 3126 & 1563 & 3478 & 1739 & 4533 & 5043 & 3,2 \\
\hline Fejér & 3663 & 1832 & 3744 & 1872 & 5311 & 5429 & 3,0 \\
\hline Gyôr-Sopron & 3335 & 1668 & 3695 & 1848 & 4836 & 3358 & 3,2 \\
\hline Hajdú-Bihar & 3479 & 1740 & 3974 & 1987 & 5045 & 5762 & 3,3 \\
\hline Heves & 2151 & 1076 & 2595 & 1297 & 3119 & 3763 & 3,5 \\
\hline Komárom-Esztergom & 2907 & 1454 & 2924 & 1462 & 4215 & 4240 & 2,9 \\
\hline Nógrád & 1536 & 768 & 1823 & 912 & 2227 & 2643 & 3,4 \\
\hline Pest & 8282 & 4141 & 8309 & 4155 & 12009 & 12048 & 2,9 \\
\hline Somogy & 1966 & 983 & 2409 & 1210 & 2851 & 3493 & 3,6 \\
\hline Szabolcs-Szatmár-Bereg & 2495 & 1248 & 3318 & 1659 & 3618 & 4811 & 3,9 \\
\hline Jász-Nagykun-Szolnok & 2746 & 1373 & 3255 & 1628 & 3982 & 4720 & 3,4 \\
\hline Tolna & 1618 & 809 & 1915 & 958 & 2346 & 2777 & 3,4 \\
\hline Vas & 1707 & 854 & 2163 & 1082 & 2475 & 3136 & 3,7 \\
\hline Veszprém & 3115 & 1558 & 3369 & 1685 & 4516 & 4885 & 3,1 \\
\hline Zala & 1997 & 998 & 2375 & 1188 & 2896 & 3444 & 3,5 \\
\hline Budapest & 31990 & 15995 & 24511 & 12256 & 46386 & 35541 & 3,8 \\
\hline Ország & 89986 & 44997 & 89912 & 44968 & 130480 & 130393 & 2,9 \\
\hline
\end{tabular}

"Forrás: Pénzügyi Számítástechnikai Intézet

11. TÁBLÁZAT

Változatok az 1989. évi SZJA-ra. II.

\begin{tabular}{|c|c|c|c|c|c|c|c|}
\hline & $\begin{array}{r}\text { Az } 198 \\
\text { ges }\end{array}$ & tényle- & $\begin{array}{r}\text { Az } 1989 . \\
\text { 16,1 \%-án }\end{array}$ & $\begin{array}{l}\text { adóalap } \\
\text { negfeleló }\end{array}$ & $\begin{array}{c}\text { Az } 1989 \\
\text { évi tényle- } \\
\text { ges adó } \\
145 \% \text {-a }\end{array}$ & $\begin{array}{c}\mathrm{Az} 1989 \text {. évi } \\
\text { adóalap ará- } \\
\text { nyában le- } \\
\text { bontott adó } \\
145 \%-\mathrm{a}\end{array}$ & Max/min \\
\hline & $100 \%$ & $50 \%$ & $\begin{array}{l}\text { millió forint } \\
100 \%\end{array}$ & $50 \%$ & & & \\
\hline Budapest & 31990 & 15995 & 24511 & 12256 & 46386 & 35541 & 3,8 \\
\hline Vidéki megyeszékhelyek & 18621 & 9310 & 17879 & 8939 & 27000 & 25926 & 3,0 \\
\hline $\begin{array}{l}\text { Többi vidéki város } \\
\text { Önálló tanácsú nagyköz- }\end{array}$ & 19514 & 9757 & 21180 & 10590 & 28295 & 30712 & 3,1 \\
\hline $\begin{array}{l}\text { ség vagy község } \\
\text { Közös tanácsok székhely- }\end{array}$ & 9910 & 4955 & 12485 & 6243 & 14370 & 18103 & 3,7 \\
\hline községei & 6507 & 3254 & 8739 & 4369 & 9435 & 12671 & 3,9 \\
\hline Társközségek & 3444 & 1722 & 5192 & 2596 & 4994 & 7528 & 4,4 \\
\hline Ország & 89986 & 44993 & 89986 & 44993 & 130480 & 130480 & 2,9 \\
\hline
\end{tabular}

"Forrás: Pénzügyi Számítástechnikai Intézet 
szóltak, s ez felelt volna meg a parlamenti választások időszakában hirdetett pártprogramoknak is. Ezért nehéz elfogadható magyarázatot és mentséget találni arra, hogy az adóváltozatok kidolgozására hivatott vagy ebben érdekelt kormányzati szervek, valamint a pártok és más érdekképviseleti csoportok gazdasági szakértối miért hagyták figyelmen kívül egy ilyen, a nemzetközi gyakorlatban is bevált elosztási rendszer alkalmazási lehetốségét.

Az 50\% erejéig elvont személyi jövedelemadót zömmel az állandó népesség és az óvódások, valamint az általános iskolai tanulók arányában osztották el újra az önkormányzati költségvetéshez való normatív állami hozzájárulás formájában. Az újraelosztás során ezért azok a települések jårtak a legrosszabbul, amelyekben az országos átlag felett volt az egy állandó lakosra jutó tényleges adó nagysága, ezzel szemben az országos átlag alatt volt az óvódások és általános iskolások száma. A személyi jövedelemadó 50\%-os elvonása és az önkormányzati költségvetéshez való normatív állami újraelosztás kereteiben való újraelosztása a budapesti önkormányzatokat érintette a legsúlyosabban: ebben az évben 16 milliárd forint SZJA bevételtôl esnek el a szabályozás új rendszerének következtében. Vezetôik 20 milliárd forintos költségvetési hiányt emlegetnek, amit megfelelố tömegử helyi adóval, áremelésekkel, támogatásleépítésekkel stb. tudnának csak megszüntetni. Míg azonban a fốváros adózó népességének túlnyomó többsége valószínưleg úgy viszonyul az adóval bruttósitott béréból levont SZJA 50\%-ának központi elvonásához, hogy azt nem ,,ô fizette" eredetileg sem, addig arra feltehetôleg nagyon érzékenyen reagálna, ha az 1989. évi SZJA elvonása és az egyéb okok miatt létrejött 1991. évi költségvetési hiányt - hacsak részben is - az ố zsebéból kivett pénzzel kívánnák csökkenteni. Ezért a budapesti önkormányzatok a legérdekeltebbek az olyan adózási változatokban, amelyek nem a két évvel korábbi, hanem a folyó költségvetési év adóbevételeit osztanák el az önkormányzatok között, s ezt az érdeküket nyilvánosan is kifejezésre juttatták az önkormányzatok gazdálkodásával kapcsolatos vitákban 1991 elsố hónapjaiban.

Az persze nyilvánvaló, hogy a központi költségvetés bevételei végesek. Ezért ha a költségvetés a folyó évi személyi jövedelemadó bevételbôl jelentôs mértékben többet engedne át a helyi önkormányzatoknak, mint amennyit jelenleg átenged, akkor módosítani, mégpedig csökkenteni kellene az önkormányzatok költségvetéséhez való normatív állami hozzájárulás, és az egyéb célú állami támogatások mértékét. Egy ilyen változat azonban egyrészrôl kevesebb lavírozási lehetổséget biztosítana a központi kormányzat számára a folyó évi személyi jövedelemadó bevételének két évvel azelốtti adóbevétel összegén felüli részét illetôen, másrészról nem igényelné, illetve nem tenné szükség címén lehetôvé a részletes központi betekintést a helyi önkormányzatok ügyeibe. Talán ezeknek az összefüggéseknek sem volt kis szerepe abban, hogy a személyi jövedelemadó elosztásának 1990 végén elfogadott rendszere más alapelvekre épül. 


\section{Jegyzetek}

${ }^{1}$ A személyi jövedelemadó és a tanácsi gazdálkodás, Tervgazdasági Közlemények, 1988/3.

${ }^{2}$ Pénzügyi Szemle, 1987. 10-11-12. 788. és 807. o.

${ }^{3}$ Magyar Közlöny, 1991. január 1. 3. o.

\section{SOME REGIONAL ASPECTS OF PERSONAL INCOME TAX}

\section{CSABA KOVÁCS}

In Hungary in 1988, the highly progressive system of personal income tax was elaborated with the idea, that the whole amount of the tax payable would be the income of state budget. The representatives of the parliament accepted the draft with the condition, that the tax payable after personal incomes would be due to the local councils (governments) at the permanent place of residence of the tax payers. The great regional differences of incomes liable to taxation, the immense differences in the proportion of actual tax-payers by settlements, and the highly progressive tax all together resulted in unjustifiable differences among the amounts of taxes paid by the residents of certain local governments per one tax payer and per one permanent resident, and also among their amount as compared to the incomes and expenditures of local governments.

On the one hand, the author discusses and proves that with the introduction of a less progressive or linear tax system, these significant regional differences could have been avoided. On the other hand he argues, that through the redistribution of progressive income tax according to the basis of assessment or after-tax income of the settlements, the extent of the regional differences of personal income taxes due to the local councils or governments could have been decreased. The author also proves that the above methods of reditsribution might substitute those which were applied by the financial authorities in order to decrease the spatial differences of income-tax revenues due to the local governments.

Transl. J. Mészáros 